\title{
Upaya Preventif Prostitusi dan Pelecehan Seksual Dalam Perspektif Dakwah
}

\section{(Preventive Efforts for Prostitution and Sexual Harassment in Da'wah Perspectives)}

\author{
Penmardianto $^{1 凶}$, Heru Permana Putra ${ }^{2}$ \\ ${ }^{1}$ Program Studi Komunikasi dan Penyiaran Islam/Institut Agama Islam Negeri Bukittinggi, Indonesia \\ ${ }^{2}$ Program Studi Komunikasi dan Penyiaran Islam/Institut Agama Islam Negeri Bukittinggi, Indonesia

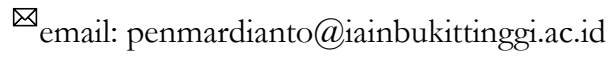

\begin{tabular}{ccc}
\hline First received: & Revised: & Final Accepted: \\
13 March 2021 & 27 May 2021 & 23 June 2021 \\
\hline
\end{tabular}

\begin{abstract}
Sexual crimes, both in the form of prostitution and in the form of sexual harassment, are increasing nowadays in people's lives, almost every time we hear information about the occurrence of sexual crimes. This crime is very dangerous to society as a whole, because the impact caused by this sexual crime is truly terrible, including: disruption of the stability of social life, rampant sexually transmitted diseases (aids), disruption of family survival and so on. Therefore, this sexual crime is a big problem for the community and a solution must be found. Islam provides solutions to solve this big problem, namely through the way of da'wah. For this reason, da'wah must be able to be a solution so that this sexual crime can be minimized, when it needs to be stopped. So the da'wah must be able to take concrete steps, so that every treatment and activity that will lead to this sexual crime can be disconnected. So this article discusses prostitution and sexual harassment in a dakwah review.
\end{abstract}

Keywords : Prostitution; Sexual Harassment; Da'wah; Islam.

\begin{abstract}
ABSTRAK
Kejahatan seksual baik dalam bentuk prostitusi maupun dalam bentuk, pelecehan seksual semakin meningkat dewasa ini dalam kehidupan masyarakat, hampir setiap saat kita dengar informasi terjadinya kejahatan seksual. Kejabatan ini sangat membahayakan masyarakat secara keseluruban, karena dampak yang ditimbulkan dari kejahatan seksual ini sunggub luar biasa mengerikan, diantaranya: terganggunya stabilitas kehidupan sosial, maraknya penyakit menular/kelamin (aids), terganggunya ketahanan kehidupan keluarga dan lain sebagainya. Oleh sebab itu kejahatan seksual ini merupakan masalah besar bagi masyarakat yang harus dicarikan solusinya. Islam memberikan solusi untuk menyelesaikan persoalan besar ini, yaitu melalui jalan dakwah. Untuk itu dakwah harus mampu menjadi solusi agar kejahatan seksuaal ini dapat diminimalisir, kapan perlu dihentikan. Maka dakwah harus mampu mengambil langkah kongkrit, agar setiap perlakuan dan kegiatan yang akan menjerumuskan kepada kejahatan seksual ini bisa di putus matarantainya. Maka dalam artikel ini membahas prostitusi dan pelecehan seksual dalam tinjauan dakwah.
\end{abstract}

Kata kunci : Prostitusi; Pelecehan Seksual; Dakwab; Islam.

\section{PENDAHULUAN}

Kecenderungan seksual terhadap lawan jenis adalah sebuah fitrah dan anugerah dari Allah kepada setiap pria dan wanita. Bagi pria, wanita selalu diletakkan sebagai salah satu mahakarya Tuhan yang selalu mendapat apresiasi meskipun relatif. Bagi pria, penilaian pertama terhadap setiap wanita adalah fisiknya, mulai dari wajah hingga bagian-bagian tubuh wanita lain yang dinilai memiliki nilai sensualitas tersendiri. Hal ini sejalan dengan salah satu pepatah Minangkabau "condong mato ka nan rancak" (mata (pria) cenderung tertarik kepada yang bagus/cantik/menarik).(Franzia et al., 2015). Di sisi lain, banyak wanita memang memandang pria dari segi wajah dan fisik, tetapi tidak seperti pria yang mayoritas mendewakan fisik wanita. 
Pada akhirnya, wanita akan lebih menilai pria dari sifat dan etikanya ketika memperlakukan wanita dari pada fisiknya. Tidak heran jika wanita akan lebih banyak melontarkan pendapat personal dengan memilih pria yang perhatian dan tanggung jawab, bukan sekedar mapan dan tampan.(Winarsih \& Putri, 2017).

Apresiasi pria terhadap fisik wanita sebenarnya adalah hal yang lumrah. Dalam Islam, pria sudah diberikan rambu-rambu dalam memilih wanita sebagai teman hidupnya. Dalam salah satu Hadis Nabi Muhammad disebutkan bahwa wanita dipilih oleh pria (biasanya) karena empat hal; fisiknya, keturunannya, kekayaannya, dan agama/etikanya. Di ujung Hadis dijelaskan bahwa Nabi Muhammad lebih menyarankan untuk memilih wanita karena agamanya karena dapat membawa keberuntungan berupa kelanggengan. Kita tidak berbicara empat faktor ini, tetapi faktor pertama yang disebutkan Nabi Muhammad adalah kecenderungan pria kepada pemilihan fisik wanita. Secara konteks Hadis tersebut, hal tersebut merupakan sebuah kewajaran bagi pria dalam memandang wanita.(Hasanah \& Salmi, 2017).

Sayangnya, pengamatan pria terhadap fisik wanita secara berlebihan membawa dampak negatif bagi kehidupan sosial, baik bagi wanita maupun pria. Terlebih bebasnya aurat wanita yang dapat dieksplorasi para pria baik secara langsung maupun tidak langsung (di dunia maya). (Kertamukti et al., 2018). Seringkali, dorongan libido pria karena apresiasi berlebihan terhadap wanita menghilangkan rasa malu dan hormat para pria kepada wanita sehingga timbul hasrat untuk mengekspoitasi fisik wanita secara langsung atau yang biasa disebut dengan pelecehan seksual. (Zimbardo et al., 2016).

Meskipun sebenarnya pelecehan seksual bukan hanya dari pria kepada wanita tetapi dapat juga terjadi sebaliknya, namun karena mayoritas pelakunya adalah pria dan korbannya adalah wanita, setiap mendengar kata pelecehan seksual secara otomatis akan menempatkan wanita sebagai korban. Memang, secara medis dikatakan bahwa libido wanita lebih tinggi dari pria, tetapi mata pria Allah jadikan lebih liar dari pada wanita. Maka dari itu pria dianjurkan untuk berdoa agar wanitanya dijadikan sebagai "qurrata 'ain" (penyejuk pandangan mata).

Bertolak dari mata pria kepada wanita, aktivitas pelecehan seksual sebenarnya adalah kontak fisik antara pria dan wanita yang dilakukan dengan unsur paksaan. Pemaksaan bisa berupa tindakan kasar secara fisik seperti pencabulan atau pemerkosaan atau dengan rayuan atau iming-iming tertentu yang pada akhirnya lebih menguntungkan pria seperti kegiatan prostitusi. Prositusi dapat dikategorikan sebagai salah satu tindakan pelecehan seksual karena mengeksploitasi fisik wanita dengan kontrak transaksi tertentu. Di satu sisi, prostitusi membawa keuntungan materil bagi wanita penjaja fisiknya. Tetapi tidak sedikit wanita yang terlibat kegiatan prostitusi ini dikarenakan tuntutan yang memaksanya untuk melakukan hal tersebut. Baik karena diawali pelecehan seksual maupun tuntutan ekonomi.

Baik pelecehan seksual maupun prostitusi, keduanya, dalam Islam masuk ke dalam ranah hukum Zina yang dalam Alquran jelas-jelas terlarang bahkan untuk sekedar mendekati perbuatan tersebut. Tambahan lagi, keliaran mata hingga membawa ke angan-angan bahkan sampai kepada aktifitas pemaksaan seksual secara fisik, seluruhnya juga tergolong zina jika dilakukan pada obyek terlarang.(Amalia, 2018).

Setiap manusia tidak akan lepas dari kesalahan dan dosa. Namun ditegaskan oleh Nabi Muhammad bahwa hal terbaik saat kita bersalah dan terjatuh dalam dosa adalah bangkit untuk bertaubat memperbaiki diri.(Nurbani, 2019). Khususnya dalam kasus prostitusi dan pelecehan seksual di Indonesia bahkan di dunia, hingga hari ini tidak sedikitpun menunjukkan penurunan angka terjadinya kasus-kasus ini. Jika menilik kembali redaksi ayat Alquran tentang larangan zina dan konsekuensi sosial akibat perzinahan serta hukuman pezina yang dijelaskan dalam Hadis dan Hukum Islam, setiap kali ada penyebutan larangan menunjukkan bahwa perbuatan tersebut akan selalu muncul dan harus selalu dihindari. Sama halnya dengan redaksi-redaksi perintah dalam Alquran, sejatinya setiap ada perintah, menunujukkan bahwa hal tersebut relatif 
sulit untuk dikerjakan sesuai arahan, maka diperlukan pernyataan perintah untuk mengingatkan.

Tingginya dan konsistennya angka perzinahan dalam bentuk prostitusi dan pelecahan seksual, menuntut sebagian kita untuk melakukan tindakan penurunan angka kasus-kasus tersebut. Sebagai manusia, bertanggungjawab untuk memperbaiki kerusakan baik secara fisik lingkungan maupun mental. (Hasan \& Abdullah, 2020). Perbaikan kerusakan mental masyarakat ini lah yang dalam bahasa Islam disebut dengan dakwah atau mengajak sesama manusia dan makhluk lain untuk tetap konsisten berada dalam koridor positif berbingkai Islam.

Dalam tiga urutan pencegahan penyakit masyarakat yang dijelaskan Nabi Muhammad, pertama adalah antisipasi dengan "tangan" atau diartikan sebagai kekuatan dan kewenangan yang dimiliki hingga jika diperlukan, dapat melakukan tindakan tegas. Kedua adalah dengan "lisan" yaitu dengan mengajak dengan damai, mengayomi, menyadarkan, dan saling mengingatkan untuk tetap berbuat hal-hal yang positif dan tidak merusak diri dan lingkungan. Ketiga adalah pencegahan personal dengan "hati", yaitu upaya menghindari dan menolak perbuatan maksiat mulai dari diri sendiri. Sebagai umat sosial yang saling membutuhkan satu sama lain, urutan ketiga ini dinilai sebagai kondisi terlemah dalam berdakwah. Namun urutan pertama, tidak semua orang dapat melakukannya. Untuk itu, setidaknya upaya pada urutan kedua, yaitu dengan berdakwah baik secara verbal maupun tindakan menjadi opsi yang dapat dikerjakan secara masif.(Aziz \& Santoso, 2020).

Dakwah dapat menjadi sarana implementasi kompetensi keilmuan manusia sebagai manifestasi dari ilmu-ilmu Allah. (Rezi, 2018). Dalam perkembangan dunia seperti sekarang ini, media dakwah sudah sangat meluas dan variatif seperti penggunaan media massa baik luring seperti koran, majalah, dan buletin, maupun daring seperti media sosial, televisi, dan lainnya. (Ahmad Zaini, 2015). Upaya preventif prostitusi dan pecehan seksual sebenarnya sudah banyak dilakukan sejak dahulu dengan berbagai metode. Sebut saja yang sedang viral adalah metode Gus Miftah yang melakukan ceramah langsung di kelab-kelab malam (Kosmawijaya, 2019) dan lokalisasi. (Muslimin Ritonga \& Dewi Sartina, 2020). Tambahan lagi, metode bernuansa wasathiyah yang juga dilakukan KH. Khoiron Syuaib di lingkungan lokaslisasi kota Surabaya dengan pendekatan adaptif, responsif dan humoris. (Sunarto, 2013). Selain itu, instansi dan organisasi juga sudah dan terus berupaya mencegan kenaikan angka pelecehan seksual dan prostitusi di berbagai daerah. Eneng (Yusmiati, 2020) dalam artikelnya menunjukkan pentingnya peran Pembimbing Kemasyarakatan dalam pencagahan pelecehan seksual dengan mengambil latar penelitian di Garut Jawa Barat. Begitu juga dengan penelitian Fitri Yani dan Ihsan (Yani \& Ihsan, 2020) yang menggambarkan peran konkrit salah satu ormas dalam mencegah kegiatan prostitusi dengan latar penelitian kota Medan. Begitu juga dengan penelitian-penelitian tentang peran dakwah dalam mencegah pelecehan seksual dan prostitusi lainnya.

Senada tetapi berbeda dengan penelitian-penelitian yang pernah dilakukan terkait dakwah pada prostitutsi dan pelecehan seksual ini, artikel ini memuat upaya-upaya preventif dan responsif dalam membantu menekan angka prostitusi dan pelecehan seksual. Upaya yang dijelaskan berbentuk penjelasan deskriptif tentang urgensi dakwah verbal dan tindakan dalam mencegah dua aktifitas negatif tersebut. Diharapkan dengan penyajian teoritis, dapat menjadikan tulisan ini lebih ringan untuk dikonsumsi khalayak umum dari semua kalangan. Selain itu, deengan pembahasan deskriptif, diharpkan dapat menjadi bantuan sumber bagi seluruh pendakwah dan penggerak aktifitas sosial dalam menekan angka prostitusi dan pelecehan seksual dengan tetap menerapkan prinsip Islam wasathiyyah (Busyro et al., 2019) dengan tidak melakukan tindakan kekerasan dan radikal di balik alasan Nahi Mungkar. 


\section{METODE PENELITIAN}

Seperti yang sudah dijelaskan sebelumnya, artikel ini adalah penelitian pustaka yang memuat analisa deskriptif dari berbagai sumber tertulis, baik buku-buku hingga berita-berita. Sumber utama penelitian ini adalah ayat-ayat Alquran yang kemudian dijelaskan melalui langkahlangkah penafsiran konkrit seperti yang diusung Ibn Taymiyyah dengan penafsiran ayat Alquran bertahap. (Rezi, 2020). Langkah nyata yang dilakukan dalam artikel ini adalah dengan mengeksplorasi makna pada diksi-diksi terkait untuk kemudian menimbang pendapat para ahli dan dikaitkan dengan realita dakwah yang terjadi. Selain itu, sumber sekunder dari penelitian ini adalah buku-buku Tafsir Alquran dan buku-buku sosial terkait dakwah, prostitusi dan pelecahan seksual.

\section{PROSTITUSI; TINJAUAN TEORITIS}

Kata "prostitusi" berasal dari bahasa Latin yaitu "prostituere" yang artinya "menyerahkan diri dengan terang-terangan kepada perzinahan". Perkataan prostisusi juga dihubungkan dengan perkataan "prostare” yang berarti "menjual, menjajakan.". (Simanjuntak, 1985).

Di Indonesia, istilah prostitusi dikenal dengan "pelacuran" yang berarti "sebagai penyerahan badan atau fisik wanita dengan pembayaran, kepada orang laki-laki guna pemuasan nafsu seksuil orang-orang itu atau juga disebut istilah WTS (Wanita Tuna Susila). Selain berorientasi kepada pihak wanita, juga sebenarnya pelacuran laki-laki juga ada, khususnya di Eropa tetapi tidak umum untuk Asia dan Indonesia. Pelacuran laki-laki ini berprofesi melacur untuk memuaskan wanita-wanita kesepian dengan tujuan mendapatkan imbalan. (Soejono, 1970).

Dari keterangan di atas maka prostitusi (pelacuran) dalam makalah ini mencakup wanita maupun laki-laki yang menyerahkan dirinya untuk memuaskan nafsu seksual secara terangterangan di luar perkawinan yang sah.

Sejalan dengan perkembangan sejarah, pelacuran tumbuh subur selama abad ke 19 bersamaan dengan perkembangan insdustri di kota-kota besar terutama di negara-negara Barat.

Bentuk-bentuk pelacuran beraneka ragam ada yang langsung tersedia misalnya di rumah-rumah bordil. Ada pula hanya melayani panggilan-panggilan untuk diajak ke suatu tempat tertentu (call girl) dan bentuk lainnya adalah pelacur jalanan yang menjajakan dirinya secara terang-terangan. Selain bentuk ini, bentuk-bentuk pelacuran juga dikategorikan pada tiga kategori yaitu kelas rendahan, kelas menengah dan pelacuran kelas tinggi. Ketiga kategori ini ditentukan oleh tarip mahal murahnya si pelacur. Bentuk lain adalah pelacur nonprofesional dan profesional. (Subet \& Daud, 2019).

Masalah pelacuran adalah suatu hal yang tidak berdiri sendiri tetapi menyangkut dengan banyak hal yang melatar belakanginya. Menurut Soedjono D. (Soejono, 1970) terdapat beberapa faktor penyebab pelacuran ditinjau sebagai berikut:

a. Faktor eknomi; kemiskinan, ingin hidup mewah dan lain-lain.

b. Faktor sosiologi seperti ; urbanisasi, keadilan sosial dan lain-lain.

c. Faktor psychologis; seperti: rasa ingin balas dendam, malas bekerja, histeris dan lain-lain.

Faktor ekonomi merupakan salah satu aspek dari sekian banyak penyebab tumbuh suburnya pelacuran. Aspek ekonomoi ini muncul disebabkan karena kemiskinan. Menurut Seokanto (Soekanto, 1997), secara sosiologis sebab timbulnya kemiskinan karena salah satu lembaga kemasyarakatan bidang ekonomi tidak berfungsi dengan baik. Selain itu, imperialisme (penjajahan), peperangan dan urbanisasi yang mengakibatkan gagal mendapatkan pekerjaan. 
Di samping penyebab di atas juga disebabkan adanya permintaan dari pihak laki-laki yang senang adanya pelacuran. Masalah ini juga disebabkan banyak faktor seperti misalnya takut kawin, tidak puas dalam perkawinan, bypersex dan lain sebagainya.

Meskipun sekian banyak faktor penyebab munculnya pelacuran namun menurut Gutttmacher sebagaimana dikutip GW. Bawengan (Bawengan, 1991) mengemukakan bahwa "pelacuran lebih bersifat problematik sosial-ekonomi daripada psikiatri." Menurut hemat penulis justru sebaliknya, bahwa pelacuran lebih bersifat psikologis daripada aspek sosial ekonomi karena mental yang baik tidak melahirkan perbuatan yang tidak baik. Oleh sebab itu, pelacur dapat dikatakan psikopat (sakit jiwa).

Dari berbagai penyebab pelacuran yang komplek tersebut secara langsung maupun tidak langsung akan memelihara tetap adanya drama prostitusi dari masa ke masa dan sulit untuk ditanggulangi.

Setiap penyimpangan dari norma-norma adat istiadat, moral dan agama akan menimbulkan akibat negatif tidak saja terhadap pribadi yang melakukannya tetapi juga bagi orang lain dan kehidupan sosial. Demikian pula prostitusi mengakibatkan beragam bentuk. (Sukmana \& Sari, 2017).

a. Menebarkan dan menyebar-luaskan penyakit kelamin, kulit dan sejenisnya.

b. Merusak sendi-sendi kehidupan keluarga yang wajar.

c. Cenderung menciptakan kejahatan dalam berbagai variasinya (tempat berkumpulnya bandit-bandit dan lain-lain)

d. Merusak sendi-sendi pendidikan moral, karena bertentangan dengan agama, susila dan hukum.

Tidak dapat disangkal bahwa prostitusi memegang peranan penting dalam penyebaran penyakit-penyakit kelamin. Namun demikian, tidak semua penyakit kelamin disebabkan oleh pelacuran karena ada wanita-wanita atau gadis-gadis yang melakukan hubungan seksual di luar perkawinan atas dasar suka sama suka dan iseng tanpa menerima bayaran. Walaupun mereka tidak disebut pelacur juga merupakan penghubung dari penularan penyakit menular. Sumber penyakit kelaminnya bukan dari mereka sendiri tetapi dari laki-laki dengan siapa ia melakukan hubungan kelamin.

Di samping pelacuran mengakibatkan penularan penyakit juga mengakibatkan rusaknya sendi-sendi kehidupan lembaga perkawinan. Bagi suami yang tidak mendapatkan kepuasan seksual dalam rumah tangga cenderung ke pelacuran. Demikian pula, ada laki-laki yang takut kawin atau tidak mampu melaksanakan perkawinan maka satu-satu jalan yang paling murah untuk menyalurkan nafsu seksualnya adalah pelacuran.

Pelacuran juga menciptakan kejahatan dalam berbagai variasinya dan berkumpulnya bandit-bandit. Selain menciptakan kejahatan, pelacuran jelas merusak dan menodai sendisendi norma agama, susial adan hukum.

Memperhatikan dari akibat banyaknya bahaya pelacuran maka pelacuran mutlak harus ditanggulangi tidak saja karena akibat-akibatnya yang membahayakan, tetapi juga agar gejala ini tidak diterima oleh masyarakat sebagai pola budaya. Pelacuran yang dibiarkan tanpa dicegah dan ditanggulangi lambat laun dapat dipandang masyarakat sebagai hal yang normal dan wajar.

\section{Pelecahan Seksual Terhadap Anak dan Permasalahannya}

Sebagai salah satu bagian gejala sosial, pelecahan seksual sulit untuk membatasi pengertiannya secara seragam. Hal ini sangat berkaitan dengan latar belakang perbedaan nilai-nilai sosial budaya masyarakat. Prilaku yang kurang etis secara susila pada suatu lingkungan, tetapi di lingkungan lain dianggap biasa saja. Pengertian etis atau tidak etisnya suatu prilaku tergantung pada lingkungan kebudayaannya. 
Istilah pelecahan merupakan perbuatan dan pandangan si peleceh kepada yang dilecehkan karena kata "leceh" mengandung arti "menghinakan, memandang rendah (tidak berharga) mengabaikan. Seksual berarti yang berkenaan dengan jenis kelamin (laki-laki dan perempuan). (Purwadinata, 1982). Dari pengertian ini, pelecahan seksual dapat berarti menghinakan, memandang rendah (tidak berharga) dan mengabaikan terhadap jenis kelamin laki-laki dan perempuan atau yang berhubungan dengan masalah seksual.

Istilah pelecahan seksual merupakan terjemahan dari kata sexual harrasment. Menurut kamus Inggris - Indonesia, kata harrasment merupakan kata benda berarti : gangguan, godaan, usikan. Sedangkan harras sebagai kata kerja berarti: menggoda, mengganggu, mengusik.(Echols \& Shadily, 1987).

Pelecahan seksual (sexual harrasmen) lebih dikenal sebagai issue perempuan yang merebak paska 70an. Kemudian pelecahan seksual marak dibicarakan sesudah tahun 1975. Tahun 1976 sebuah majalah di Amerika Serikat bernama Redbok melakukan penelitian bahwa 9000 pembaca perempuan, $88 \%$ dari perempuan tersebut menyatakan pernah mengalamai sexual harrasmen sebagai korban dan $92 \%$ mengakui bahwa pelecahan seksual merupakan perseolan serius yang dihadapi oleh perempuan. Penelitian yang sama juga pernah dilakukan di Amerika oleh Majalah bernama MS , tahun 1991. 43 \% dari 4450 perempuan pernah diperlakukan tidak senonoh, baik di lingkungan pekerjaan maupun sekolah. Dari penelitian itu disimpulkan bahwa setiap perempuan dari berbagai lapisan masyarakat, dari berbagai umur, ras dan pekerjaan sangat rentan terhadap perlakuan seksual yang tidak diinginkan. (Tong, 1984).

Sudarsono (Sudarsono, 1998) mendefinisikan istilah sexual harrasmen sebagai "Gangguan/ godaan/ usikan, perlakuan seksuil yang merusak kepribadian atau kedudukan, misalnya perbuatan seksual di muka umum atau terhadap anak buah oleh atasannya". Dari kutipan di atas secara sederhana sexual harrasment (pelecahan seksual) berarti gangguan, godaan, usikan, rabaan yang berhubungan dengan masalah seksual.

Rosemarie Tong (Tong, 1984) memberikan kondisi-kondisi yang menunjukkan terjadinya pelecahan seksual antara lain; adanya gangguan atau perlakuan "seksual" yang tidak diinginkan oleh perempuan, seperti lirikan atau kerlingan, colekan, elusan dan lain-lain.; Ungkapan-ungkapan yang negatif atau positif terhadap diri perempuan, seperti pantatnya bahenol, disuit-suit, dll.; Adanya tekanan atau paksaan "seksual" oleh seseorang yang lebih berkuasa kepada perempuan yang berada di bawah kekuasaannya, peristiwa ini berlanjut terusmenerus, seperti dokter terhadap pasiennya, dosen terhadap mahasiswanya, bos terhadap bawahannya dll.

Quick dan Fayden (Quick \& McFadyen, 2017), menjelaskan bahwa Sexual harrasment (pelecahan seksual) adalah semua tindakan seksual atau kecenderungan bertindak secara seksual yang bersifat intimidasi non fisik (kata-kata, bahasa, gambar) dan fisik (gerakan yang kasat mata seperti memegang, menyentuh, meraba, mencium bagian-bagian tubuh tertentu) yang dilakukan oleh seseorang atau kelompok lain. Tindakan itu dipahami sebagai tindakan merendahkan, mengabaikan, mencemarkan keberadaan pihak yang bersangkutan sebagai manusia sesama harkat.

Berdasarkan definisi di atas maka pelecahan seksual adalah tindakan seksual berupa gangguan, usikan, godaan, baik yang bersifat non fisik maupun fisik yang menghinakan dan memandang rendah terhadap masalah seksual. Tindakan tersebut dapat merendahkan dan mencemarkan serta mengakibatkan penderitaan secara fisik, seksual dan psikologis. Dari pengertian in, semua bentuk kejahatan terhadap kesusilaan mulai dari yang subtil misalnya mengedip-ngedipkan mata sampai dengan menggunakan kekerasan adalah pelecahan seksual.

Pengertian pelecahan seksual seperti diungkapkan di atas bersifat umum dan tidak terkecuali terhadap anak-anak. Tegasnya, pelecahan seksual masuk kategori kejahatan seksual karena tergolong pada perbuatan cabul. Dengan demikian, bentuk lain yang dapat 
dikategorikan sebagai pelecahan seksual adalah pornografi, prostitusi dan perkosaan, homo seksual atau lesbian. Hal ini disebabkan kerena pelaku kecabulan, pelacuran dan perkosaan dan sejenisnya menganggap rendah terhadap masalah seksual.

Berdasarkan literatur yang ada, secara khusus pembahasan tentang pelecahan seksual terhadap anak-anak belum ditemukan. Meskipun demikian, tindakan kejahatan seksual yang mencakup terhadap anak-anak sebagai tindak pidana termuat dalam Bab XIV Buku II KUHP pasal 289 tentang kejahatan terhadap kesusilaan. Untuk lebih jelasnya bunyi pasal 289 tersebut adalah sebagai berikut:

"Barang siapa dengan kekerasan atau ancaman kekerasan memaksa seseorang melakukan atau membiarkan dilakukan pada dirinya perbuatan cabul, dibukum karena merusak kesopanan dengan bukuman penjara selama-lamanya sembilan tahun".

R. Soesilo (Soesilo, 1976) menafsirkan maksud pasal di atas adalah "segala perbuatan yang melanggar kesusilaan (kesopanan), atau perbuatan yang keji. Semuanya itu dalam lingkungan nafsu birahi, misalnya cium-ciuman, meraba-raba anggota kemaluan, meraba-raba buah dada dan sebagainya." Atas dasar ini maka pelecahan seksual baik terhadap anak maupun terhadap orang dewasa masuk dalam kategori kejahatan seksual.

\section{Faktor Penyebab Pelecehan Seksual}

Dewasa ini masalah pelecehan seksual semakin marak dibicarakan orang. Kiranya agak sukar menentukan faktor-faktor apakah yang menjadi sebabnya. Namun tak dapat pula dikesampingkan bahwa faktor-faktor kemajuan teknologi dan ekonomi jelas ikut perperan di dalamnya.

Uraian-Uraian yang diketengahkan mengenai faktor-faktor penyebab pelecehan seksual bukanlah suatu hasil penelitian empiris, melainkan sebagian besar merupakan hipotesahipotesa para ahli yang harus dilengkapi dengan penelitian-peelitian lebih lanjut. Atas dasar inilah pemakalah dapat mengatakan bahwa faktor penyebab timbulnya pelecehan seksual secara pasti sukar ditentukan baik ditinjau dari segi aspek dan dimensi kehidupan manusia.

Menurut B. Simanjuntak (Simanjuntak, 1985), bahwa terjadinya pergeseran nilai-nilai seks sebagian besar disebabkan beberapa faktor, yaitu; 1) Adanya emansipasi wanita yang mulai tersebar di seluruh dunia; 2). Kehidupan sekuler yang makin intensif dan makin kurangnya peranan agama dalam kehidupan sosial manusia; 3). Makin renggangnya kehidupan keluarga karena funsi keluarga semakin banyak diambil oper oleh lembaga-lembaga kemasyarakatan; 4). Makin majunya teknologi, khusus dalam bidang komunikasi massa, 5). Kehidupan perkotaan yang kurang menjalin hubungan sosial primer dan melemahkan sosial kontrol khusus dalam kehidupan seks.

Kelima faktor penyebab di atas dapat memungkinkan timbulnya pelecehan seksual di mana-mana. Secara psikologis, kasus pelecehan seksual ini tergantung kepada kepribadian atau moral individu pelaku dan korban, namun secara sosiologis masalah ini jelas tidak bisa dipisahkan dari persepsi sosio-kultural masyarakat Indonesia khususnya yang masih menempatkan perempuan sebagai makhluk kedua. Makhluk yang sudah semestinya melayani kebutuhan seksual laki-laki.

Adanya partisipasi wanita yang mulai tersebar di belahan dunia pada berbagai lapangan pekerjaan memungkinkan terjadinya pelecehan seksual. Meskipun potensi-potensi intelektual, emosional dan estetika seta keterampilan wanita dapat seimbang dengan laki-laki, akan tetapi nilai masyarakat sering tidak memberikan kesempatan untuk mengembangkan bakat yang dimilikinya. Oleh karena itu wanita secara riil lebih banyak mempunyai nilai reaktif yang dapat mengundang nafsu birahi laki-laki.

Pelecehan seksual memungkinkan terjadi di lapangan kerja jika kekuasaan laki-laki terkonsentrasi pada satu pihak, lalu yang menjadi korbannya adalah perempuan yang menjadi 
bawahannya. Ketidak berdayaannya terhadap atasannya memungkinkan atasan bisa bertindak leluasa kepadanya.

Faktor penyebab kedua timbulnya pelecehan seksual adalah kehidupan sekuler yang makin intensif serta makin kurangnya peranan agama dalam kehidupan sosial manuasia.

Dalam suatu nilai yang mengatur secara ketat kehidupan seks dalam masyarakat adalah agama. Manakala sistem nilai agama ini telah terpengaruh oleh budaya modernisasi dan sekuralisasi, maka peran agama semakin lama semakin hilang.

Kurangnya pendidikan agama dalam kepribadian seseorang akan terpengaruh oleh buaian dunia dan budaya yang tidak sesuai dengan nilai-nilai yang diajarkan oleh agama. Munculnya prilaku yang tidak etis, baik di tempat-tempat umum maupun di tempat lainnya akibat pengendalian diri sudah lepas, dan peranan agama tidak mendominasi dalam kepribadiannya.

Perubahan nilai-nilai seks yang ketiga disebabkan oleh semakin renggangnya kehidupan keluarga. Oleh karena fungsi keluarga semakin banyak diambil alih oleh lembaga kemasyarakatan.

Faktor ketiga ini tidak menutup kemugkinan terjadinya pelecehan seksual. Kurangnya pendidikan dan kasih sayang yang diberikan oleh orang tua kepada anaknya dapat menimbulkan tingkah laku yang tidak baik.

Akibat kemajuan teknologi dan semakin gencarnya manusia mencari kehidupan material sehingga fungsi keluarga menjadi hilang sama sekali. Ini akan menimbulkan ketegangan di dalam keluarga.

Faktor keempat yang memungkinkan timbulnya pelecehan seksual adalah disebabkan kemajuan teknologi, khususnya dalam bidang komunikasi massa. Kemajuan ilmu dan teknologi memang patut dibanggakan karena banyak membawa perubahan yang begitu cepat. Akan tetapi disamping membawa dampak positif, juga membawa dampak negatif.

Ilmu komunikasi massa yang mengabdikan kepada kepentingan komersial dan ekonomi menyebarkan nilai-nilai baru tentang kehidupan seks dalam masyarakat. "televisi, majalah, layar putih merupakan media massa yang menghadapkan kepada masyarakat normanorma seks baru.(Simanjuntak, 1985).

Menurut ahli kriminologi bahwa salah satu sebab munculnya kejahatan di kalangan masyarakat adalah pengangguran. Hal ini sesuai dengan pendapat Hari Suherijo (Suherijo, 1980), "pengangguran, tidak adanya pekerjaan akan sedikit banyak mempengaruhi pula tingkah laku seseorang. Kondisi yang demikian ini tidak menutup adanya pelecehan seksual dilakukan oleh orang-orang pengangguran yang hanya sekedar iseng atau bahkan menjurus kepada perkosaan.

Seks merupakan energi psikis yang mendorong manusia untuk aktif bertingkah laku. Sigmund Freud menyebut seks sebagai libido seksual yang mendorong manusia untuk bertinkahlaku yang disebutnya sebagai the pleasure principle. (Dahlan, 1985).

Maka dalam kaitan tersebut, manusia memiliki dorongan seks tidaklah selamanya normal dan ada yang abnormalitas seks. Perempuan disebut memiliki seks yang normal dan dewasa manakala ia mampu mengadakan relasi seks dengan laki-laki dalm bentuk yang normal dan bertanggung jawab. Demikian juga sebaliknya. Pria disebut normal dan dewasa apabila mampu mengadakan relasi seks secara normal dan bertanggung jawab, dalam hal ini mengadakan hubungan seks berdasarkan perkawinan yang sah dan teratur. Sedangkan abnormalitas dan pervers buruk dan jahat yang disebabkan oleh dorongan-dorongan seks yang abnormal. Dorongan seks yang abnormal ini menurut Kartini Kartono diantaranya adalah pornografi dan prottage, yaitu kepuasan seks dengan meraba-raba orang lain. (Kartono, 1992). 


\section{PROSTITUSI DAN PELECAHAN SEKSUAL DALAM PERSPEKTIF DAKWAH}

Prostitusi dan pelecahan seksual merupakan penyimpangan terhadap norma agama dan moral, Kedua bentuk ini mengakibatkan bahaya baik ditinjau dari aspek psikologis maupun sosiologis sehingga kedua penyimpangan ini masuk dalam ranah patologi sosial.

Ajaran Islam memandang bahwa prostitusi maupun pelecahan seksual merupakan perbuatan dosa/ keji dan melanggar larangan Allah SWT, sebagaimana firman dalam surat alA'raf ayat 33 :

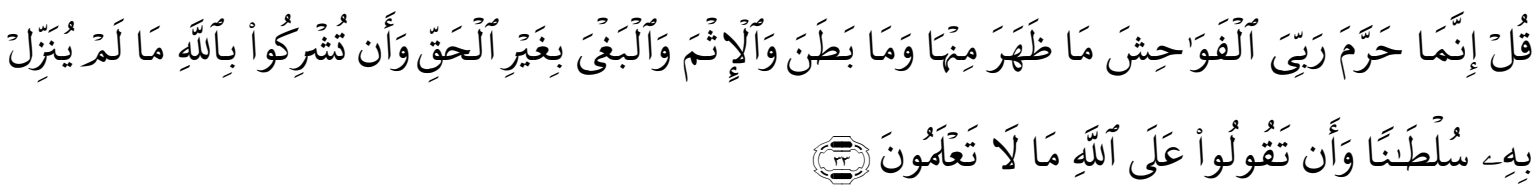

Katakanlah: "Tuhanku hanya mengharamkan perbuatan yang keji, baik yang nampak ataupun yang tersembunyi, dan perbuatan dosa, melanggar bak manusia tanpa alasan yang benar, (mengharamkan) mempersekutukan Allah dengan sesuatu yang Allah tidak menurunkan bujjah untuk itu dan (mengharamkan) mengada-adakan terhadap Allah apa yang tidak kamu ketabui."(Departemen Agama RI, 1987)

Selain ayat di atas terdapat banyak ayat yang memerintahkan untuk meninggalkan halhal yang keji antara lain (QS. 4; 31), (QS.17; 32), (23; 5 dan 10, 11), (42; 37), 53;32), $(70 ; 29,30,31)$. Di samping perintah meninggalkan hal-hal yang keji juga banyak disebutkan dalam al-Qur'an tentang kekejiaan zina misalnya dalam QS 4;24, (4;25), (5;5), (17;32), 19;28), (23'7) dan (70;31). Selain itu juga termaktub ayat yang menetapkan sanksi perzinahan seperti : (QS.24;2, 25).

Dari beberapa ayat yang terdapat dalam al-Qur;an yang membicarakan masalah zina maka QS. An-Nur ayat 2 lebih khusus membicarakan tentang pelacuran sebagaimana firmanNya: :

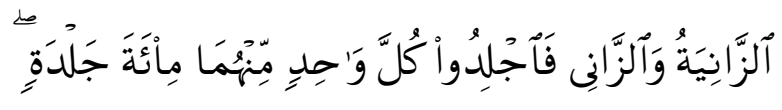

"Perempuan yang beriina dan laki-laki yang berzina, Maka deralah tiap-tiap seorang dari keduanya seratus kali dera”.

Mustafa Mahmud al-Mahdawi (Mahmud, 1986) berpendapat bahwa laamul-ma'rifat dalam ayat di atas menunjukkan pezina laki-laki dan perempuan yang terus-menerus atau secara langsung terus-menerus melakukan perzinahan sebagai jalan hidupnya, atau menjadikannya sebagai profesi. Sedangkan sanksi bagi yang yang terjerumus dalam perzinahan akibat lemahnya keimanan maka dikenakan hukum berdasarkan ayat QS. An-Nisa' ayat 16. Demikian pula sanksi bagi istri yang melakukan perzinahan dikenakan hukum penjara berdasarkan ayat 15 surat An-Nisa'.

Setiap larangan yang terdapat dalam ajaran Islam jelas mengandung mudharat/ bahaya baik bagi kehidupan pribadi maupun masyarakat. Demikian halnya dengan pelacuran dan pelecehan seksual sebagaimana telah diuraikan pada bagian terdahulu.

Mengingat bahaya yang ditimbulkan kedua bentuk penyimpangan tersebut sangat besar bagi pribadi maupun terhadap kehidupan sosial maka harus ditanggulangi. Penangulangan terhadap penyimpangan ini dilaksanakan tidak saja karena akibat-akibatnya yang membahayakan tetapi juga agar gejala ini diterima oleh masyarakat sebagai pola budaya yang dilegalkan. Dengan pengertian lain, pelacuran dan pelecehan seksual yang tidak ditanggulangi lambat laun dipandang oleh masyarakat sebagai hal yang normal dan wajar serta besar kemungkinan akan melembaga sebagai suatu hal yang wajar. 
Berbagai usaha dalam menanggulangi pelacuran sejak dulu sampai sekarang telah dilakukan umat manusia di berbagai belahan dunia mulai dari hukum yang ringan sampai kepada hukuman yang berat seperti hukum gantung, bagi germo-germo, pelacur, calo-calo dan tamu-tamu lacur tetapi belum dapat diatasi.

Berbagai teori bermunculan dalam rangka usaha penanggulangan penyimpangan seksual ini seperti tindakan preventif, tindakan represip dan tindakan kuratif namun dalam kenyataannya pelacuran tidak bisa dibasmi.

Penanggulan pelacuran dan pelecahan seksual sungguh sangat berat karena menyangkut banyak aspek yang melatar belakanginya, Oleh karena itu, tanpa melibatkan campur tangan Sang Khalik niscaya penyimpangan seksual tersebut akan sulit diatasi.

Berdasarkan hal tersebut di atas maka peran dan fungsi dakwah dalam rangka penanggulan kejahatan seksual sangat diperlukan terutama menumbuh kembangkan kesadaran masyarakat agar tidak terlena dengan kehidupan menuhankan hawa nafsunya.

Sebagaimana diketahui bahwa esensi dari filosofi dakwah adalah suatu proses upaya pembentukan dan pemahaman, persepsi dan sikap al-madb'u yang sesuai dengan ajaran Islam. Kemudian, ensensi dakwah adalah perubahan dan peningkatan kualitas hidup yang mencakup upaya ishlah, tajdid dan tagyir.

Esensi filosofi dakwah dalam bidang tajdid berfungsi sebagai solusi terhadap persoalan kemanusiaan yaitu rekonstruksi sosial (social reconstruction) yaitu perbaikan kehidupan masyarakat dalam segala aspek kehidupan. Oleh karena itu, menurut Amis Rais (Rais, 1991), "segala macam rekonstruksi masyarakat multidimensional, sama dengan dakwah."

Peran dakwah terhadap pelacuran dan pelecahan seksual dalam tataran operasional adalah berfungsi sebagai preventif yaitu upaya pencegahan terhadap munculnya pelacuran dan pelecahan seksual. Metode yang dapat digunakan adalah metode manizah al-hasanah dalam bentuk tarbiyah. Pola pencegahan terhadap kejahatan seksual ini dapat berbentuk" moralistik dan abolisionalistik".(Soerdjono, 1985).

Pendekatan moralistik dimaksudkan sebagai suatu usaha untuk menanggulangi tindakan-tindakan kejahatan seksual melalui pemantapan mental spiritual umat agar kebal terhadap bujukan-bujukan yang bersikap negatif.

Agar dakwah Islam mampu memberikan dampak terhadap penanggulangan pelacuran dan pelecahan seksuam maka yang pertama sekali harus dibangun adalah pemantapan akidah al salimah. Akidah yang disampaikan kepada al-madh' $u$ bukan semata-mata berkaitan dengan eksistensi dan wujud Allah, akan tetapi yang lebih penting adalah menumbuhkan kesadaran yang mendalam untuk memanifestasikan nilai-nalai tauhid dalam merasa, ucapan, pikiran dan tindakan sehari-hari, baik terhadap pribadi maupun masyarakat pada umumnya.

Jadi akidah yang diajarkan adalah akidah yang bersifat mubarrikah yang menggerakkan kesadaran dan ketundukan kepada Allah, ridho dan rela secara utuh kepada Allah, cinta dan benci karena Allah, serta akidah yang menumbuhkan penghambaan secara kaffah kepada Allah dan tidak kepada selain-Nya.

Upaya-upaya pencegahan terhadap penyimpangan seksual ini sebenarnya telah lama dikenal dalam Islam, yaitu melarang manusia untuk melakukan perbuatan-perbuatan yang keji dan mungkar seperti larangan mendekati zina (lihat QS. Al Isra' ayat 32).

Sedangkan upaya penanggulangan dengan cara abolisionalistik dimaksud untuk menghilangkan atau memperkecil motif-motif yang melatar belakangi masalah pelacuran dan pelecahan seksual, seperti misalnya meningkatkan derajat kehidupan ekonomi masyarat melalui pengentasan kemiskinan, memperkokoh keutuhan rumah tangga dan lain sebagainya.

Persoalan dakwah adalah menyangkut segala aspek kehidupan manusia dan berkaitan dengan upaya perbaikan yang tidak mengenal selesai. Selama manusia ada di bumi ini, proses konfrontatif antara kebenaran dan kebatilan, antara ma'ruf dan mungkar, antara seruan kepada jalan Allah dan seruan kepada jalan Syaitan tetap berlangsung sehingga dakwah tetap ada. 
Menurut Didin Hafidhuddin (Hafidhuddin, 1998) di samping materi dakwah pembentukan akidah sebagai isu utama dan besar, juga perlu mendapat perhatian serius dari pelaksana dakwah menyangkut yang pemenuhan kebutuhan masyarakat.

Senada dengan hal di atas, Rosyad Shaleh (Shaleh, 1977) mengemukakan bahwa dalam bidang ekonomi, proses da'wah antara lain berupa ikut mencarikan jalan keluar dalam mendapatkan lapangan kerja serta memberikan dorongan agar setiap orang mendapatkan kesempatan yang sama dalam memperoleh pekerjaan dan dalam mengolah dan memanfaatkan sumber-sumber kekayaan alam yang dikaruniakan oleh Allah SWT kepada umat manusia.

Ajaran Islam menjadikan ibadah yang mempunyai aspek sosial sebagai landasan membangun sistem penanganan masalah seperti kemiskinan. Jika masalah kemiskinan dapat diatasi maka faktor salah satu faktor penyebab munculnya pelacuran akan dapat dihilangkan.

Di samping pemantapan akidah dan penyebaran rasa keadilan sosial, juga perlu meningkatkan political will pemerintah terhadap masalah pelacuran dan pelecehan seksual, misalnya dalam meregulasi perundang-undangan tentang pelacuran dan pelecahan seksual.

Oleh karena itulah, Sayyid Quthub (Quthub, 1992) mengemukakan dalam tafsirnya, bahwa dalam rangka menegakkan akidah Islamiyah dalam kehidupan manusia maka mengharuskan ada dua kelompok dalam Islam yaitu pertama yang menyeru kepada kebajikan dan kelompok kedua menyuruh kepada yang ma'ruf dan mencegah dari yang munkar. Perintah dan larangan akan dapat terwujud manakalah ada kekuasaan serta kedua kelompok tersebut harus bersatu padu dalam mewujudkan tujuan dakwah tersebut. Dengan demikian, pemantapan political will pemerintah perlu mendapat perhatian dari penyelenggara dakwah Islamiyah.

Langkah selanjutnya dalam rangka mengatasi persoalan pelacuran dan pelecahan seksual adalah melalui pendekatan kuratif yaitu pengobatan dan pengentasan. Metode dakwah yang digunakan adalah mau'izhah al hasanah dalam bentuk tauzih wal irsyad (Bimbingan konseling).

Selain usaha preventif dan kuratif, juga dapat dilakukan dengan cara represif. Tindakan represif artinya melaksanakan hukuman sesuai dengan konsep ajaran Islam terhadap pelaku pelacuran dan pelecehan seksual. Dengan adanya hukuman yang sesuai dengan ajaran Islam maka diharapkan mampu mendorong kesadaran masyarakat agar takut melakukan perbuatan tersebut terutama bagi orang-orang yang sudah dihukum untuk tidak mengulangi perbuatannya. Peran dakwah dalam konteks ini adalah mendorong pemerintah dan seluruh elemen masyarakat agar melaksanakan hukum-hukum Allah.

\section{PENUTUP}

Prostitusi dan pelecahan seksual merupakan bentuk penyimpangan seksual yang menimbulkan bahaya bagi kehidupan pribadi dan masyarakat. Oleh sebab itulah masalah pelacuran dan pelecehan seksual masuk dalam ranah patologi sosial. Penanggulan pelacuran dan pelecahan seksual sungguh sangat berat karena menyangkut banyak aspek yang melatar belakanginya, Oleh karena itu, tanpa melibatkan campur tangan Sang Khalik niscaya penyimpangan seksual tersebut akan sulit diatasi. Atas dasar hal ini maka esensi dakwah terhadap persoalan ini berfungsi sebagai preventif, represif dan kuratif.

\section{DAFTAR PUSTAKA}

Ahmad Zaini. (2015). Dakwah Melalui Televisi. At-Tabsyir; Journal of Islamic Broadcasting Communication, https://journal.iainkudus.ac.id/index.php/komunikasi/article/view/1642 
Amalia, M. (2018). PROSTITUSI DAN PERZINAHAN DALAM PERSPEKTIF HUKUM ISLAM. Tabkim (Jumal Peradaban Dan Hukum Islam), 1(1), 68-87. https://doi.org/10.29313/tahkim.v1i1.3265

Aziz, A., \& Santoso, R. (2020). NAHI MUNGKAR DALAM DAKWAH (Konstruksi Hadis Dakwah Terhadap Pengembangan Dakwah). In TASAMUH (Vol. 18, Issue 2). https://doi.org/10.20414/TASAMUH.V18I2.2766

Bawengan, G. (1991). Pengantar Psikologi Kriminil. Pradnya Paramita.

Busyro, B., Ananda, A. H., \& Adlan, T. S. (2019). Moderasi Islam (Wasathiyyah) di Tengah Pluralisme Agama Indonesia. FUADUNA: Jurnal Kajian Keagamaan Dan Kemasyarakatan, 3(1), 1. https://doi.org/10.30983/fuaduna.v3i1.1152

Dahlan, M. (1985). Beberapa Pendekatan dalam Penyuluban (Konseling). Diponegoro.

Departemen Agama RI. (1987). Al-Qur'an dan Terjemahnya. Toha Putra.

Echols, J. M., \& Shadily, H. (1987). Kamus Inggris-Indonesia. Gramedia.

Franzia, E., Pialang, Y. A., \& Saidi, A. I. (2015). Representasi Identitas Melalui Komunikasi Visual Dalam Komunitas Virtual Palanta Urang Awak Minangkabau. Panggung, 25(4). https://doi.org/10.26742/panggung.v25i4.45

Hafidhuddin, D. (1998). Dakwah Aktual. Gema Insani Press.

Hasan, W. R., \& Abdullah, M. F. R. (2020). Menangani Masalah Zina menurut Perspektif alQuran dan Sunnah. The Sultan Alauddin Sulaiman Shah Journal (JSASS), 7(1), 49-63. http://jsass.kuis.edu.my/index.php/jsass/article/view/13

Hasanah, H., \& Salmi, S. (2017). NILAI EDUKASI KASIH SAYANG DALAM KEHIDUPAN RUMAH TANGGA RASULULLAH SAW. Jurnal Dedikasi Pendidikan, 1(2), 184-191. http://103.52.61.43/index.php/dedikasi/article/view/82

Kartono, K. (1992). Patologi Sosial Jilid 1. Rajawali Press.

Kertamukti, R., Nugroho, H., \& Wahyono, S. B. (2018). Komunikasi Visual: Fantasi Tubuh Wanita Kelas Menengah di Instagram. Jurnal Kajian Komunikasi, 6(2), 231. https://doi.org/10.24198/jkk.v6i2.17925

Kosmawijaya, T. (2019). Da’i Diskotik: Dakwah Gus Miftah di tempat Hiburan Malam Yogyakarta. UIN Sunan Ampel.

Mahmud, M. (1986). Menangkap Isyarat Alquran (Tim Pustaka Firdaus (ed.); Terjemahan). Pustaka Firdaus.

Muslimin Ritonga, \& Dewi Sartina. (2020). Komunikasi Dakwah Gus Miftah di Lokalisasi Pasar Kembang Yogyakarta. Al-Munzir, 13(2), 273-294. https://doi.org/10.31332/AM.V13I2.2051

Nurbani, M. (2019). Urgensi Pembahasan Taubat dalam Perspektif Hadis. Holistic Al-Hadis, 5(1), 25. https://doi.org/10.32678/holistic.v5i1.3231

Purwadinata, W. (1982). Kamus Bahasa Indonesia. Balai Pustaka.

Quick, J. C., \& McFadyen, M. A. (2017). Sexual harassment: Have we made any progress? Journal of Occupational Health Psychology, 22(3), 286-298. https://doi.org/10.1037/ocp0000054

Quthub, S. (1992). Tafsir Fi Zhilalil Qur'an Juz II (Terjemahan). Gema Insani Press. 
Rais, A. (1991). Cakrawala Islam. Mizan.

Rezi, M. (2018). Ilmu Allah Berbanding Ilmu Manusia (Studi Deskriptif Ayat-ayat Alquran). TAJDID: Jurnal Ilmu Keislaman Dan Ushuluddin, 21, 37-44. https://doi.org/10.15548/tajdid.v21i2.219

Rezi, M. (2020). Al-Tafsîr Al-Kabîr: Penafsiran Maudhu’i Ibnu Taymiyyah Dalam Balutan Tahliliy. Jurnal Ulunnuba, 9(2), 155-167. http:// ejournal.iainbukittinggi.ac.id/index.php/a

Shaleh, R. (1977). Manajemen Da'wah Islam. Bulan Bintang.

Simanjuntak, B. (1985). Patologi Sosial. Tarsito.

Soejono, D. (1970). Pathologi Sosial. Alumni.

Soekanto. (1997). Pengantar Sosiologi. Rajawali Press.

Soerdjono, D. (1985). Bungai Rampai Kriminologi. Amrico.

Soesilo, R. (1976). Kitab Undang-Undang Pidana dan Komentar-Komentarnya. Politea.

Subet, M. F., \& Daud, M. Z. (2019). Makna Denotatif dan Konotatif dalam Slanga Pelacur. MIRJO, 3(1).

Sudarsono. (1998). Kamus Filsafat dan Psikologi. Rineka Cipta.

Suherijo, H. (1980). Pokok-pokok Kriminologi. Aksara Baru.

Sukmana, O., \& Sari, R. (2017). JARINGAN SOSIAL PRAKTEK PROSTITUSI TERSELUBUNG DI KAWASAN WISATA KOTA BATU. Sosio Konsepsia, 6(2), 155166. https://doi.org/10.33007/ska.v6i2.481

Sunarto. (2013). Kiai Prostitusi: Pendekatan Dakwah K.H. Khoiron Syu'aib di Lokalisasi Kota Surabaya - Digilib UIN Sunan Ampel Surabaya. Jaudar. http://digilib.uinsby.ac.id/34087/

Tong, R. (1984). Women, Sex and the Law. Rowman Publisher.

Winarsih, S., \& Putri, D. M. (2017). REPRESENTASI FEMINISME DALAM MEDIA UNTUK PRIA TALKMEN.COM. Journal Communication Spectrum: Capturing New Perspectives in Communication, 4(1), 72-91. https://doi.org/10.36782/JCS.V4I1.1772

Yani, F., \& Ihsan, M. (2020). Peran Organisasi Kemasyarakatan Pemuda Muhammadiyah Dalam Pencegahan Prostitusi Terselubung di Kecamatan Medan Belawan. Jurnal Ilmiah Penegakan Hukum, 7(2), 117-125. https://doi.org/10.31289/JIPH.V7I2.4163

Yusmiati, E. I. (2020). Peran Pembimbing Kemasyarakatan dalam Upaya Penanganan Kasus Pelecehan Seksual Anak. JURNAL PEMIKIRAN DAN PENGEMBANGAN PEMBELAJARAN, 2(1), 1-8. jp3.com/index.php/Pendidikan/article/view/89

Zimbardo, P., Wilson, G., \& Coulombe, N. (2016). How porn is messing with your manhood. Skeptic (Altadena, CA), 21(3), 22-27. https://go.gale.com/ps/i.do?p=AONE\&sw=w\&issn=10639330\&v=2.1\&it=r\&id=GA $\mathrm{LE} \%$ 7CA464244381\&sid=googleScholar\&linkaccess=fulltext 